\title{
Giant Cell Sarcoma
}

National Cancer Institute

\section{Source}

National Cancer Institute. Giant Cell Sarcoma. NCI Thesaurus. Code C66759.

A sarcoma characterized by the presence of large, anaplastic malignant cells. 